OPEN ACCESS

Edited by:

Fuminori Mizuno,

Toyota Research Institute of North

America, USA

Reviewed by:

Yongguang Zhang,

Hebei University of Technology, China

Xiao-Liang Wang,

Seeo Inc., USA

*Correspondence: Yuichi Aihara

yuichi.aihara@samsung.com

Specialty section: This article was submitted to

Energy Storage,

a section of the journal Frontiers in Energy Research

Received: 01 February 2016 Accepted: 18 April 2016

Published: 13 May 2016

Citation:

Aihara Y, Ito S, Omoda R, Yamada T,

Fujiki S, Watanabe T, Park Y and

Doo S (2016) The Electrochemical

Characteristics and Applicability of an Amorphous Sulfide-Based Solid Ion

Conductor for the Next-Generation Solid-State Lithium

Secondary Batteries.

Front. Energy Res. 4:18.

doi: 10.3389/fenrg.2016.00018

\section{The Electrochemical Characteristics and Applicability of an Amorphous Sulfide-Based Solid Ion Conductor for the Next-Generation Solid-State Lithium Secondary Batteries}

\author{
Yuichi Aihara' ${ }^{1 *}$, Seitaro Ito ${ }^{1}$, Ryo Omoda ${ }^{1}$, Takanobu Yamada ${ }^{1}$, Satoshi Fujiki ${ }^{1}$, \\ Taku Watanabe ${ }^{1}$, Youngsin Park ${ }^{2}$ and Seokgwang Doo ${ }^{2}$ \\ 'Samsung R\&D Institute Japan, Minoo-shi, Japan, ² Samsung Advanced Institute of Technology, Samsung Electronics Co., \\ Ltd, Suwon-si, South Korea
}

Sulfide-based solid electrolytes (SEs) are of considerable practical interest for all solid-state batteries due to their high ionic conductivity and pliability at room temperature. In particular, iodine containing lithium thiophosphate is known to exhibit high ionic conductivity, but its applicability in solid-state battery remains to be examined. To demonstrate the possibility of the iodine-doped SE, Lil-Li $\mathrm{PSS}_{4}$, was used to construct two different types of test cells: Li/SE/S and Li/SE/LiNi ${ }_{0.80} \mathrm{CO}_{0.15} \mathrm{Al}_{0.05}$ cells. The SE, Lil-Li $\mathrm{Li}_{3} \mathrm{PS}_{4}$, showed a high ionic conductivity approximately $1.2 \mathrm{mS} \mathrm{cm}^{-1}$ at $25^{\circ} \mathrm{C}$. Within 100 cycles, the capacity retention was better in the Li/SE/S cell, and no redox shuttle was observed due to physical blockage of SE layer. The capacity fade after 100 cycles in Li/SE/S cell was approximately $4 \%$ from the maximum capacity observed at 10 th cycle. In contrast, the capacity fade was much larger in $\mathrm{Li} / \mathrm{SE} / \mathrm{LiNi}{ }_{0.80} \mathrm{Co}_{0.15} \mathrm{Al}_{0.05}$ cell, probably due to the decomposition of the electrolyte at the operating potential range. Nevertheless, both the $\mathrm{Li} / \mathrm{SE} / \mathrm{LiNi}_{0.80} \mathrm{CO}_{0.15} \mathrm{Al}_{0.05}$ and $\mathrm{Li} / \mathrm{SE} / \mathrm{S}$ cells exhibited high coulombic efficiencies above 99.6 and 99.9\% during charge-discharge cycle test, respectively. This indicates that a high energy density can be achieved without an excess lithium metal anode. In addition, it was particularly interesting that the SE showed a reversible capacity about $260 \mathrm{mAh} \mathrm{g}_{-\mathrm{SE}}^{-1}$ (the value calculated using the net solid electrolyte weight). This electrolyte may behave not only as an ionic conductor but also as a catholyte.

Keywords: solid-state battery, solid electrolyte, lithium-sulfur batteries, lithium secondary batteries, sulfide electrolyte, catholyte

\section{INTRODUCTION}

Nowadays, requirements for batteries have been increasingly stringent in terms of energy density and safety because of the diversity of functions of electronic devices and their usage as a power source especially in transportation. Lithium ion batteries (LIBs) have been in the market over two decades because of their high energy density, but even better batteries have been sought to meet ever stricter requirements (Scrosati and Garche, 2010). Solid-state lithium batteries have received considerable 
attention since the inception of primary and secondary lithium batteries (Weppner, 1981). From viewpoints of (1) theoretical capability and (2) physical properties, solid-state lithium batteries have been believed to be next-generation power sources. Unfortunately, the commercial applications of all solid-state batteries are limited to a few cases, such as the Li-I primary battery, and thin film type solid-state batteries because of serious technical challenges (Bates et al., 1993).

Recently, fast lithium ion conductors have been found in sulfide compounds (Kamaya et al., 2011). A large difference between typical oxide- and sulfide-based solid electrolytes (SEs) is in their physicomechanical properties, especially on their deformability. In particular, a large grain boundary resistance, observed in oxide SEs, does not unambiguously exist in many sulfide SEs because of the pliable nature of the sulfide compounds; seamless reaction interfaces can be easily formed by a cold press without high temperature sintering (Tatsumisago et al., 2002). Recently, excellent cell characteristics have been reported using a small pellet cell (Ogawa et al., 2012). Unfortunately, most of these studies adopted a Li-In alloy, because of its stable cycle due to the solid solution, unlike a dissolution-deposition reaction. As well as a conventional LIB, a rocking chair type all-solid-state battery (Ogawa et al., 2012) and Li-S battery (Nagata and Chikusa, 2014) have also been proposed. We have shown the possibility of a practical 2-Ah class all-solid LIB using a sulfide electrolyte (Ito et al., 2014). We also have investigated the anode kinetics using $\mathrm{Li}_{3} \mathrm{PS}_{4}$, i.e., $\mathrm{Li}_{2} \mathrm{~S}: \mathrm{P}_{2} \mathrm{~S}_{5}=75: 25$ (Yamada et al., 2015). Use of the solid-state electrolyte greatly facilitates the design of a highly save battery unlike the ones using flammable organic liquid solvents.

Among many sulfide compounds, lithium thiophosphates containing halogens exhibit relatively high ionic conductivities. Mercier et al. (1981) reported a structure and property relation of $\mathrm{Li}_{2} \mathrm{~S}-\mathrm{P}_{2} \mathrm{~S}_{5}-\mathrm{LiI}$ systems. They reported that the addition of $\mathrm{LiI}$ to $\mathrm{Li}_{2} \mathrm{~S}-\mathrm{P}_{2} \mathrm{~S}_{5}$ lowered the glass transition temperature, and the material had a high ionic conductivity of approximately $10^{-3} \mathrm{~S} \mathrm{~cm}^{-1}$ at $25^{\circ} \mathrm{C}$ when the molar ratio of $\mathrm{LiI}: 0.66 \mathrm{Li}_{2} \mathrm{~S}-0.33 \mathrm{P}_{2} \mathrm{~S}_{5}$ is 0.45 . Ohtomo et al. (2013) investigated the electrochemical stability and ionic conductivity of $\mathrm{LiI}-\mathrm{Li}_{2} \mathrm{O}-\mathrm{Li}_{2} \mathrm{~S}-\mathrm{P}_{2} \mathrm{~S}_{5}$ glass. They found that $30 \mathrm{LiI}-70\left(0.07 \mathrm{Li}_{2} \mathrm{O}-0.68 \mathrm{Li}_{2} \mathrm{~S}-0.25 \mathrm{P}_{2} \mathrm{~S}_{5}\right)$ is stable over $0-10 \mathrm{~V}$ and exhibited a high ionic conductivity of $1.3 \times 10^{-3} \mathrm{~S} \mathrm{~cm}^{-1}$. The stability and ionic conductivity of Li7P2S8I was reported by Rangasamy et al. (2015). They observed that the addition of iodine to the $\beta$ - $\mathrm{Li}_{3} \mathrm{PS}_{4}$-based structure resulted in good electrochemical stability against an Li metal anode while maintaining a conductivity of $6.3 \times 10^{-4} \mathrm{~S} \mathrm{~cm}^{-1}$ at room temperature. These literatures indicate that iodine-containing lithium thiophosphates have great potential and that there is considerable practical interest in investigating the applicability of this class of materials as SE in all solid-state batteries.

In this paper, we report the cell cycle characteristics longer than 100 cycles with the theoretical sulfur redox capacity plus the electrolyte redox capacity, using an amorphous $\mathrm{LiI}-\mathrm{Li}_{3} \mathrm{PS}_{4}$ electrolyte, referring with $\mathrm{LiNi}_{0.80} \mathrm{Co}_{0.15} \mathrm{Al}_{0.05}$ (NCA) cathode. To clarify the origin of the excess cell capacity from a net sulfur specific capacity, the electrolyte was also tested as a cathode. It was found that amorphous $\mathrm{LiI}-\mathrm{Li}_{3} \mathrm{PS}_{4}$ had a reversible capacity of about $260 \mathrm{mAh} \mathrm{g}^{-1}$ within the potential range of 1.3-2.7 $\mathrm{V}$ versus
$\mathrm{Li} / \mathrm{Li}^{+}$. The possibility of using a sulfide-based solid electrolyte in solid-state lithium secondary batteries using was also discussed.

\section{EXPERIMENTAL}

\section{Materials}

The solid-state electrolyte (SE), $\mathrm{LiI}-\mathrm{Li}_{3} \mathrm{PS}_{4}$, was prepared by the mechanical milling method in an Ar-gas-filled vessel was used for above preparation to prevent degradation of the sample. Specifically, $35 \mathrm{~mol} \%$ of LiI (Aldrich, $99.999 \%$ ) and $65 \mathrm{~mol} \%$ of $0.75 \mathrm{Li}_{2} \mathrm{~S}$ (Alfa, 99.9\%) $-0.25 \mathrm{P}_{2} \mathrm{~S}_{5}$ (Aldrich, 99\%) were mixed at $380 \mathrm{rpm}$ for $35 \mathrm{~h}$ (70 cycles of $20 \mathrm{~min}$ of operation and $10 \mathrm{~min}$ of interval) by using Fritsch (Idar-Oberstein) P-5 grinding bowl fasteners. The synthesized electrolyte was characterized using Raman spectroscopy (JASCO, NRS-3100, Tokyo) and X-ray diffraction (XRD, CuK $\alpha, 45$ kV, 40 mA, Panalytical, Empyrean XRD, Almelo).

$\mathrm{LiNi}_{0.80} \mathrm{Co}_{0.15} \mathrm{Al}_{0.05}$ (NCA) was coated with $\mathrm{Li}_{2} \mathrm{O}-\mathrm{ZrO}_{2}$ (LZO) and was used for the reference cathode material. The preparation of LZO-NCA was given in our previous report (Ito et al., 2014). An NCA cathode composite was prepared by mixing the LZO-NCA, $\mathrm{LiI}-\mathrm{Li}_{3} \mathrm{PS}_{4}$ and a vapor grown carbon fiber (VF, the fiber diameter: approximately $200-500 \mathrm{~nm}$, the length: approximately $5-10 \mu \mathrm{m})$ in the weight ratio of 0.60:0.35:0.05 using a mortar (hand mixing) in an Argon box (MBraun, LABmaster dp, $\mathrm{H}_{2} \mathrm{O}<0.1$ ppm, $\mathrm{O}_{2}<0.1 \mathrm{ppm}$ ).

For preparing the lithium-sulfur (Li-S) cell, the carbon-sulfur (C-S) composite was first prepared using the ball milling method. Dried sulfur powder (Alfa Aesar) was mixed with an activated carbon (MAXSORB ${ }^{\circledR}$ MSC-30, Kansai Coke and Chemicals Co., Ltd.) in the weight ratio of 26:74 wt\% in an argon-filled $45-\mathrm{mL}$ zirconia vessel by using high-energy ball milling at $370 \mathrm{rpm}$ for $10 \mathrm{~h}$ (20 cycles of $20 \mathrm{~min}$ operation and $10 \mathrm{~min}$ interval). Then, the C-S composite was further mixed with $\mathrm{LiI}-\mathrm{Li}_{3} \mathrm{PS}_{4}$ (SE) in the weight ratio 0.5:0.5 to make a carbon-sulfur-solid electrolyte (C-S-SE) composite, using the same high energy ball milling method. The mixing procedure is the same as for the $\mathrm{C}-\mathrm{S}$ preparation. The weight fraction of the prepared sulfur cathode composite was 0.37:0.13:0.50 for sulfur:carbon:LiI- $\mathrm{Li}_{3} \mathrm{PS}_{4}$. The C-SE composite (0.21:0.79) was similarly prepared using the ball milling method. Lithium foil ( $t=30 \mu \mathrm{m}$, Honjo Metal, Osaka) was used for the anode.

Differential scanning calorimetry (DSC) was performed on a SII X-DSC7000 calorimeter (Seiko SII, Tokyo) using an Ar-filled closed pan for the prepared $\mathrm{LiI}, \mathrm{Li}_{3} \mathrm{PS}_{4}, \mathrm{LiI}-\mathrm{Li}_{3} \mathrm{PS}_{4}, \mathrm{C}-\mathrm{S}-\mathrm{SE}$, and $\mathrm{C}-\mathrm{SE}$ composites. The measurements were performed between room temperature and $400^{\circ} \mathrm{C}$ with scanning rate of $2^{\circ} \mathrm{min}^{-1}$.

For the evaluation of the applicability of cathode materials, the in-house electrochemical cell (two electrodes cell, $\varphi 13 \mathrm{~mm}$ ) was adopted. The cell preparation method and the schematic structure are also described in our previous paper (Ito et al., 2014). The details of the prepared cells are listed in Table $\mathbf{1}$.

\section{Electrochemical Measurements}

The ionic conductivity of the SE was determined from the cell constant and bulk resistance observed in electrochemical 
TABLE 1 | Specification of the test cells.

\begin{tabular}{lcc}
\hline & S-cell & NCA-cell \\
\hline Cathode active material weight fraction $(\mathrm{wt} \%)$ & 37 & 60 \\
Cathode composite loading $\left(\mathrm{mg} \cdot \mathrm{cm}^{-2}\right)$ & 2.7 & 11.3 \\
Active material loading $\left(\mathrm{mg} \cdot \mathrm{cm}^{-2}\right)$ & 1.0 & 6.8 \\
Active material/carbon ratio $(\mathrm{w} / \mathrm{w})$ & 2.9 & $(12.0)$ \\
Cell capacity $(\mathrm{mAh})$ & 2.1 & 1.2 \\
Cathode area specific capacity $\left(\mathrm{mAh} \cdot \mathrm{cm}^{-2}\right)$ & 1.6 & 0.9 \\
Anode area specific capacity $\left(\mathrm{mAh} \cdot \mathrm{cm}^{-2}\right)$ & 23.2 & 23.2 \\
Anode/cathode capacity ratio & 14.5 & 25.8 \\
Utilization of anode at DOD $=100 \%(\%)$ & 6.9 & 4.0 \\
\hline
\end{tabular}

DOD, depth of discharge.

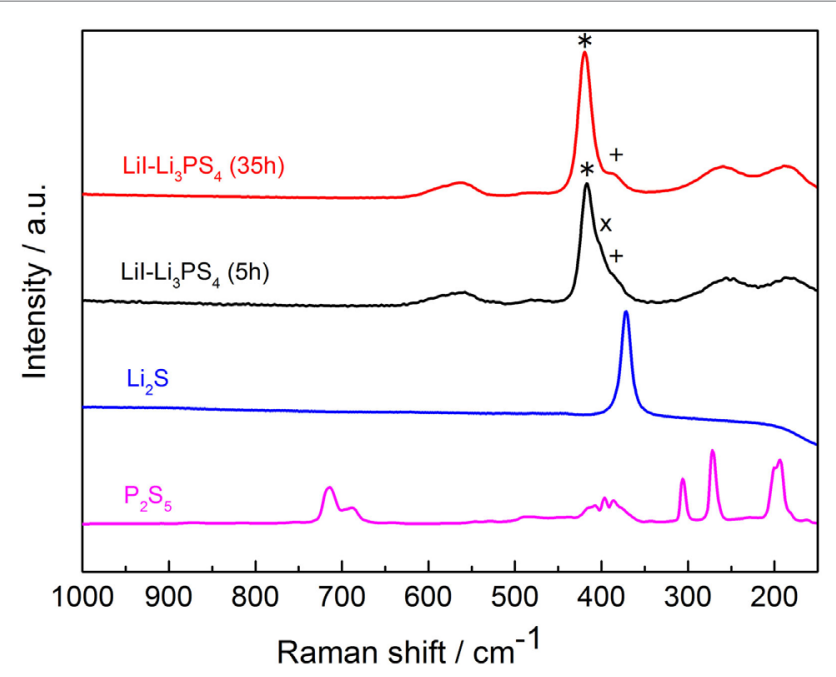

FIGURE 1 | Raman spectra of the starting materials and the solid-state electrolyte, Lil-Li $\mathrm{PS}_{4}$ after ball milling for $\mathbf{5} \mathbf{~ h}$ (black) and $35 \mathbf{h}$ (red). * $420 \mathrm{~cm}^{-1}$ : stretching of $\mathrm{PS}_{4}$ anion; ${ }^{\times} 405 \mathrm{~cm}^{-1}$ : stretching of $\mathrm{P}_{2} \mathrm{~S}_{7}$

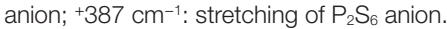

impedance spectroscopy (EIS). The EIS was performed using an AUTOLAB PGSTAT30 with an frequency response analysis FRA module (Metrohm Autolab, Utrecht) controlled by a personal computer. Linear sweep voltammetry (LSV) was performed using the same equipment. An asymmetric two electrodes cell with a Pt working electrode and a lithium counter (reference) electrode was prepared for LSV. The galvanostatic charge/discharge profiles were obtained using a battery test station, TOSCAT3100 (Toyo system, Iwaki) at $25^{\circ} \mathrm{C}$ position in a temperature chamber.

\section{RESULTS}

\section{Characterization of $\mathrm{Lil}_{-} \mathrm{Li}_{3} \mathrm{PS}_{4}$}

The crystallinity and anion structure of the SE, $\mathrm{LiI}-\mathrm{Li}_{3} \mathrm{PS}_{4}$, was characterized by Raman spectroscopy (Figure 1) and XRD (Figure 2). It is clear from the Raman spectra that the reaction proceeded because of the high-energy ball milling within the first $5 \mathrm{~h}$. After $35 \mathrm{~h}$ of ball milling, the intensities of the $\mathrm{P}_{2} \mathrm{~S}_{7}$ dimer diminished in the spectrum. However, even after $35 \mathrm{~h}$, the $\mathrm{P}_{2} \mathrm{~S}_{6}$ peak was not completely suppressed. Furthermore, some reaction

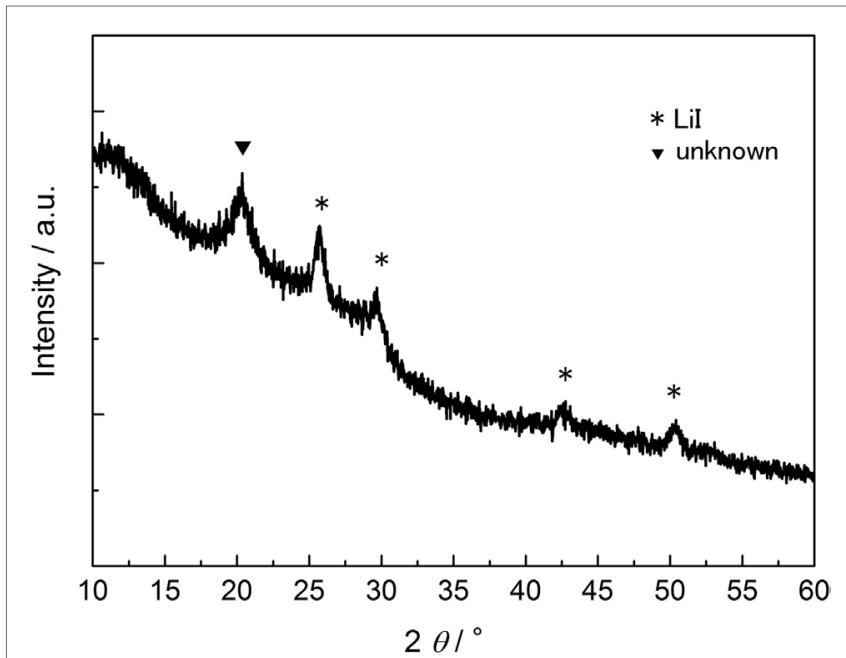

FIGURE 2 | X-ray diffraction of $\mathrm{Lil}^{-} \mathrm{Li}_{3} \mathbf{P S}_{4}$. ${ }^{*}$ Peaks assigned in the reaction residue of Lil crystalline. $\mathrm{Li}_{2} \mathrm{~S}$ was completely consumed by the reaction.

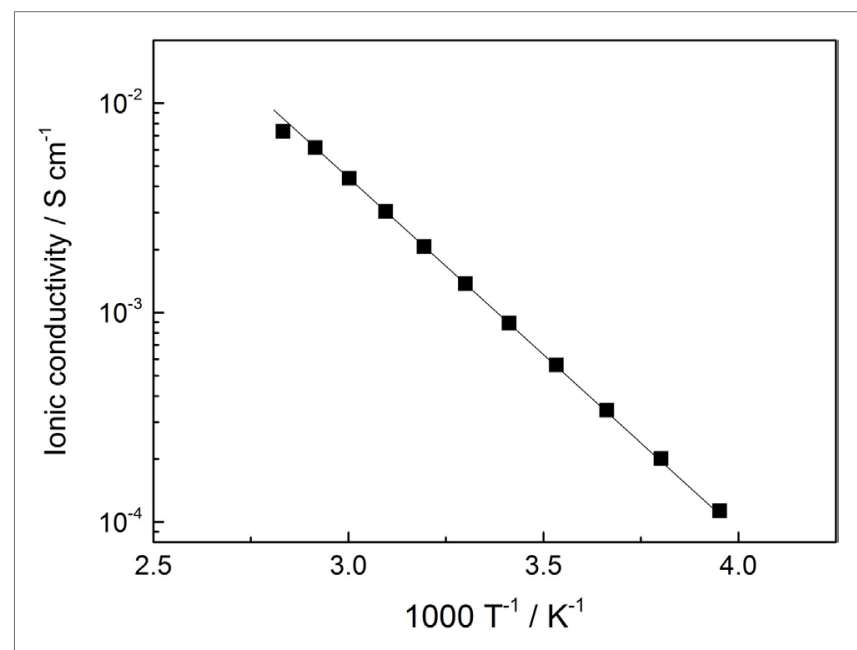

FIGURE 3 | Arrhenius plot of the ionic conductivity of $\mathrm{Lil}-\mathrm{Li}_{3} \mathrm{PS}_{4}$.

residue of LiI was found in the XRD pattern. The XRD pattern and Raman spectrum did not show any obvious change after $35 \mathrm{~h}$, and so synthesis was discontinued at this point. From the above results, the synthesized electrolyte was mostly amorphous containing a small fraction of $\mathrm{P}_{2} \mathrm{~S}_{6}$ dimer and crystalline LiI. The main anion frame structure was ortho - $\mathrm{PS}_{4}^{-}$(and $\mathrm{I}^{-}$).

The temperature dependence of the ionic conductivity for $\mathrm{LiI}-\mathrm{Li}_{3} \mathrm{PS}_{4}$ is plotted in Figure 3. The temperature dependence was a typical Arrhenius type, and the activation energy of the ionic conductivity was $29.1 \pm 1.1 \mathrm{~kJ} \mathrm{~mol}^{-1}$. The ionic conductivity was $1.2 \mathrm{mS} \mathrm{cm}^{-1}$ at $25^{\circ} \mathrm{C}$, and it is approximately 10 times than that of amorphous $\mathrm{Li}_{3} \mathrm{PS}_{4} \mathrm{SE}$ (Yamada et al., 2015).

The electrochemical stability of the electrolyte was determined using LSV (Figure 4). The potential was scanned from the open circuit potential to $5.0 \mathrm{~V}$ versus co-counter/reference electrodes of $\mathrm{Li} / \mathrm{Li}^{+}$. At $2.8 \mathrm{~V}$, a small spike peak was observed for $\mathrm{LiI}-\mathrm{Li}_{3} \mathrm{PS}_{4}$. 


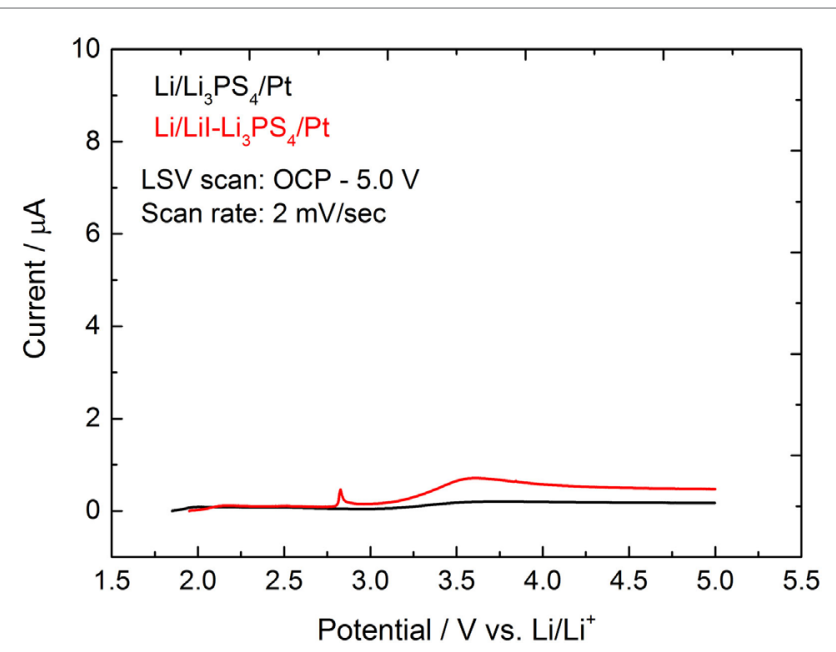

FIGURE 4 | Linear sweep voltammogram of $\mathrm{Li}_{3} \mathrm{PS}_{4}$ and $\mathrm{Lil}^{-} \mathrm{Li}_{3} \mathrm{PS}_{4}$ at $2^{\circ} \mathbf{C}$. WE: Pt, CE-RE: Li, scan rate: $2 \mathrm{mV} \mathrm{s}^{-1}$.

This peak might originate from isolated lithium iodide and its anodic oxidation. Although the anodic decomposition current was not significant, the current profile indicated a small anodic oxidation above $3.1 \mathrm{~V}$ for $\mathrm{LiI}-\mathrm{Li}_{3} \mathrm{PS}_{4}$. On the contrary, no anodic current was observed in $\mathrm{Li}_{3} \mathrm{PS}_{4}$ cell.

\section{Li/Lil-Li ${ }_{3} P_{4} /$ LZO-NCA Cell (NCA Cell)}

The discharge profiles and capacity attenuation during 100 cycles for $\mathrm{Li} / \mathrm{LiI}-\mathrm{Li}_{3} \mathrm{PS}_{4} / \mathrm{LZO}-\mathrm{NCA}$ cell (NCA cell) is shown in Figures 5A,B. The cell showed initial discharge capacities of approximately 134 and $94 \mathrm{mAh} \mathrm{g}^{-1}$ at 0.05 and $0.5^{\circ} \mathrm{C}$, respectively. These cathode specific capacities were larger than in our previous study (Ito et al., 2014). However, the specific capacity decreased from 95 to $70 \mathrm{mAh} \mathrm{g}^{-1}$ after 100 cycles with the charge/discharge condition of $0.1 \mathrm{C} \mathrm{CC}-\mathrm{CV} / 0.5 \mathrm{C} \mathrm{CC}$. The capacity fade was much faster than that in Graphite $/ \mathrm{Li}_{2} \mathrm{~S}-\mathrm{P}_{2} \mathrm{~S}_{5}$ (80:20 mol\%)/LZO-NCA (Ito et al., 2014). The initial coulombic efficiency was $69.4 \%$ and gradually increased to $99.0 \%$ by the sixth cycle. The average coulombic efficiency during the last 50 cycles was $99.6 \%$. After 100 cycles, the average cell closed potential decreased due to the increase of $i \mathrm{R}$ drop up in the first $2 \mathrm{~s}$ right after the galvanostatic charge/discharge started. These performance characteristics indicate that the cell-specific capacity gradually decreased due to the increase of cell resistance with the same cutoff potential.

\section{Li/Lil-Li $3 \mathrm{PS}_{4} / \mathrm{C}-\mathrm{S}$ Cell (S Cell)}

The discharge profiles and capacity attenuation during 100 cycles for the $\mathrm{Li} / \mathrm{LiI}-\mathrm{Li}_{3} \mathrm{PS}_{4} / \mathrm{S}$ (S cell) is shown in Figures 6A,B. On account of the expected poor rate capability of the $S$ cell, the discharge rate was fixed at $0.15 \mathrm{C}\left(0.25 \mathrm{~mA} \mathrm{~cm}^{-2}\right)$ with the charge/ discharge cut off potentials between 3.1 and $1.3 \mathrm{~V}$ (constant current charge/discharge). In Figure 6A, the discharge profiles including 1st, 10th, and 100th are shown at the same discharge rate. The initial cell capacity was only about $1300 \mathrm{mAh} \mathrm{g}_{-s}^{-1}$ (the value calculated using the net sulfur weight), lower than what is
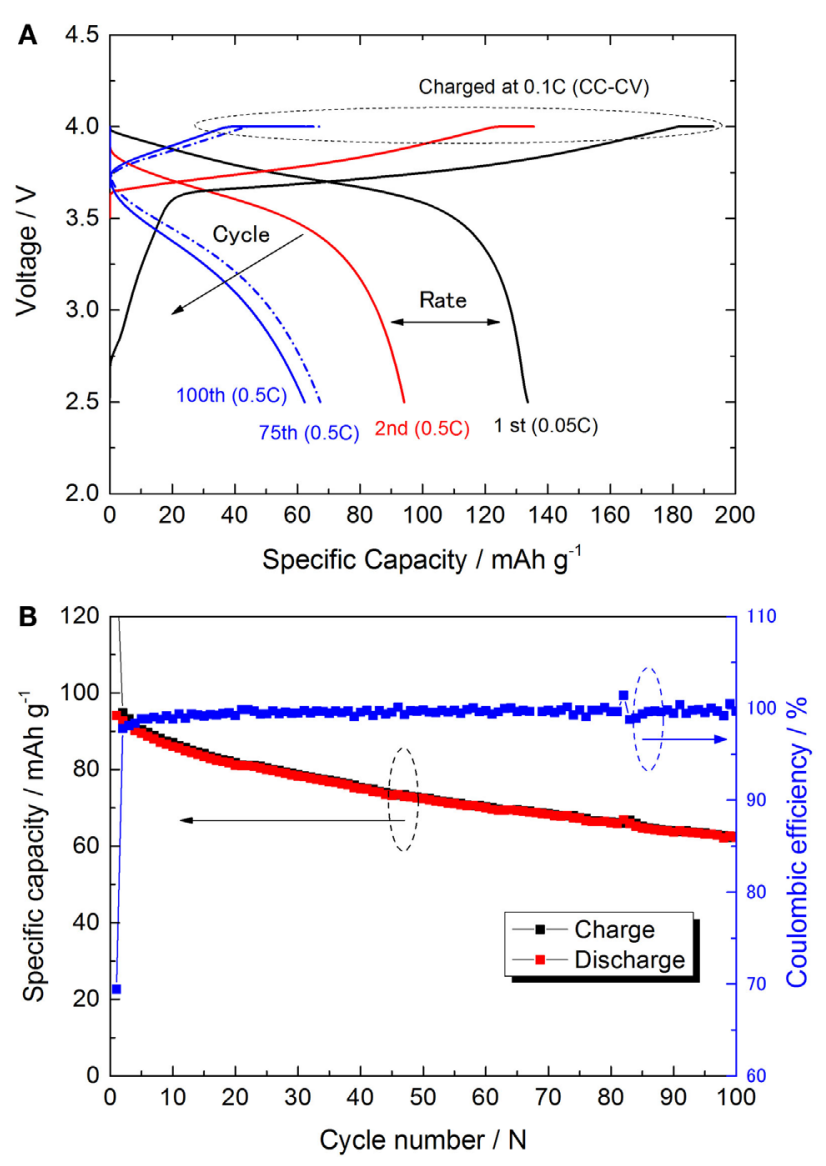

FIGURE 5 | (A) Charge/discharge curves of NCA-cell for 1st, 10th, and 100 th cycle at $25^{\circ} \mathrm{C}$. The $0.1 \mathrm{C}$ constant current-4.0 V constant voltage (CC-CV) mode was adopted for all the charge sequences. First discharge was done at $0.05 \mathrm{C}$ to check the full capacity. (B) Charge/discharge capacities and the coulombic efficiency are plotted versus the cycle (within the 2 nd cycle to 100th cycle).

expected for a $\mathrm{Li}-\mathrm{S}$ cell of this type. The specific capacity increased with the cycle and achieved a maximum value of $1688 \mathrm{mAh} \mathrm{g}_{-s}^{-1}$ (calculated using the net sulfur weight) at the 10th cycle.

After the 10th cycle, the specific capacity gradually decreased to $1622 \mathrm{mAh} \mathrm{g}_{-\mathrm{s}}^{-1}$ by 100 th cycle. The coulombic efficiency reached beyond $99.9 \%$ after the 30th cycle. From the maximum capacity obtained at the 10th cycle, the specific capacity decreased only $4 \%$ in the last 90 cycles. Also, it is clear that no redox shuttle was observed. This result is consistent with our previous report on the all-solid-state Li-S cell (Yamada et al., 2015). Unfortunately, the cycle performance was lower than the expectation. Nevertheless, in this paper, we changed the SE and the carbon support used in the cathode. Both the material change positively influenced the cell performance. The results are summarized and compared with the former NCA cell in Table 2.

\section{Li/Lil-Li ${ }_{3} \mathrm{PS}_{4} / \mathrm{C}-\mathrm{Lil}^{-} \mathrm{Li}_{3} \mathrm{PS}_{4}$ (E Cell)}

Because of the strange charge plateau above $2.5 \mathrm{~V}$, the possibility of a reversible redox reaction of the electrolyte was investigated. 


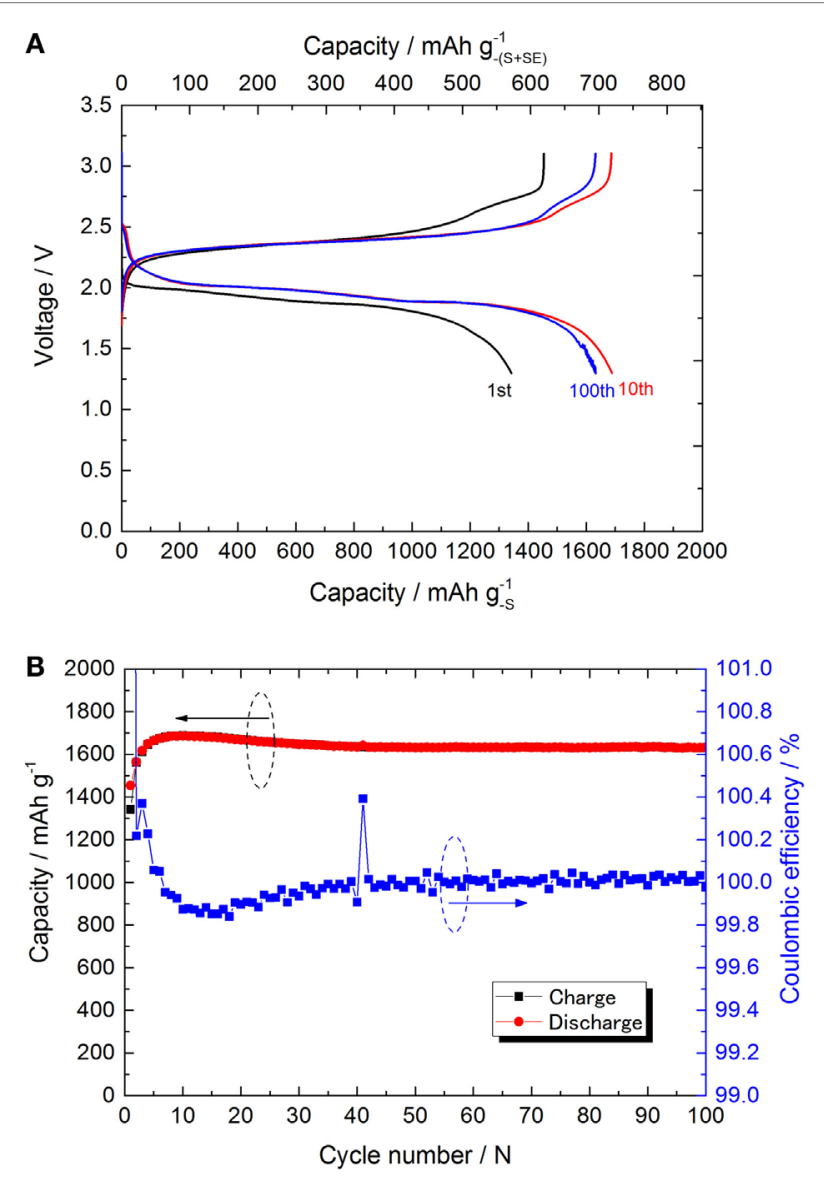

FIGURE 6 | (A) Charge/discharge curves of S-cell for 1st, 10th, and 100th cycle at $25^{\circ} \mathrm{C}$. All the charge/discharge was done at $0.15 \mathrm{C}\left(0.25 \mathrm{~mA} \mathrm{~cm}{ }^{-2}\right)$ constant current with the cutoff potential of 3.1 and $1.3 \mathrm{~V}$. (B) Charge/ discharge capacities and the coulombic efficiency are plotted versus the cycle.

TABLE 2 | Summary of the cell characteristics.

\begin{tabular}{lcc}
\hline & S-cell & NCA-cell \\
\hline${\text { Cell capacity }(\mathrm{mAh})^{\mathrm{a}}}^{\mathrm{a}}$ & 2.1 & 1.2 \\
$\mathrm{~V}_{1 / 2 \mathrm{Q}}$ at 1st cycle $(\mathrm{V})^{\mathrm{b}}$ & 1.9 & 3.7 \\
Cathode active material energy density $(\mathrm{Wh} / \mathrm{kg})^{\text {Cathode composite energy density }(\mathrm{Wh} / \mathrm{kg})}$ & 3000 & 493 \\
Average coulombic efficiency within last 50 cycles $(\%)$ & 1111 & 259 \\
${\text { Capacity retention at 100th cycle }(\%)^{c}}^{c}$ & 90.0 & 99.6 \\
\hline
\end{tabular}

axaximum capacities are adopted (S-cell: the discharge capacity at 10th cycle and NCA-cell: the discharge capacity at 1st cycle).

${ }^{b}$ The average discharge voltage was determined at the half capacity.

'The capacity retention was determined from 1st/100th capacity (S-cell) and 2nd/100th capacity (NCA-cell) to be fixed as the discharge rate.

Recently, the reversible reaction of $\mathrm{Li}_{3} \mathrm{PS}_{4}$ and "sulfur-rich lithium polysulfidophosphates" has been suggested (Lin et al., 2013; Hakari et al., 2015). Reactivity of the carbon-electrolyte (C-SE) composite was investigated using a similar cell configuration to the S-cell, but it did not contain sulfur in the cathode composite. The galvanostatic charge/discharge profile and the capacity
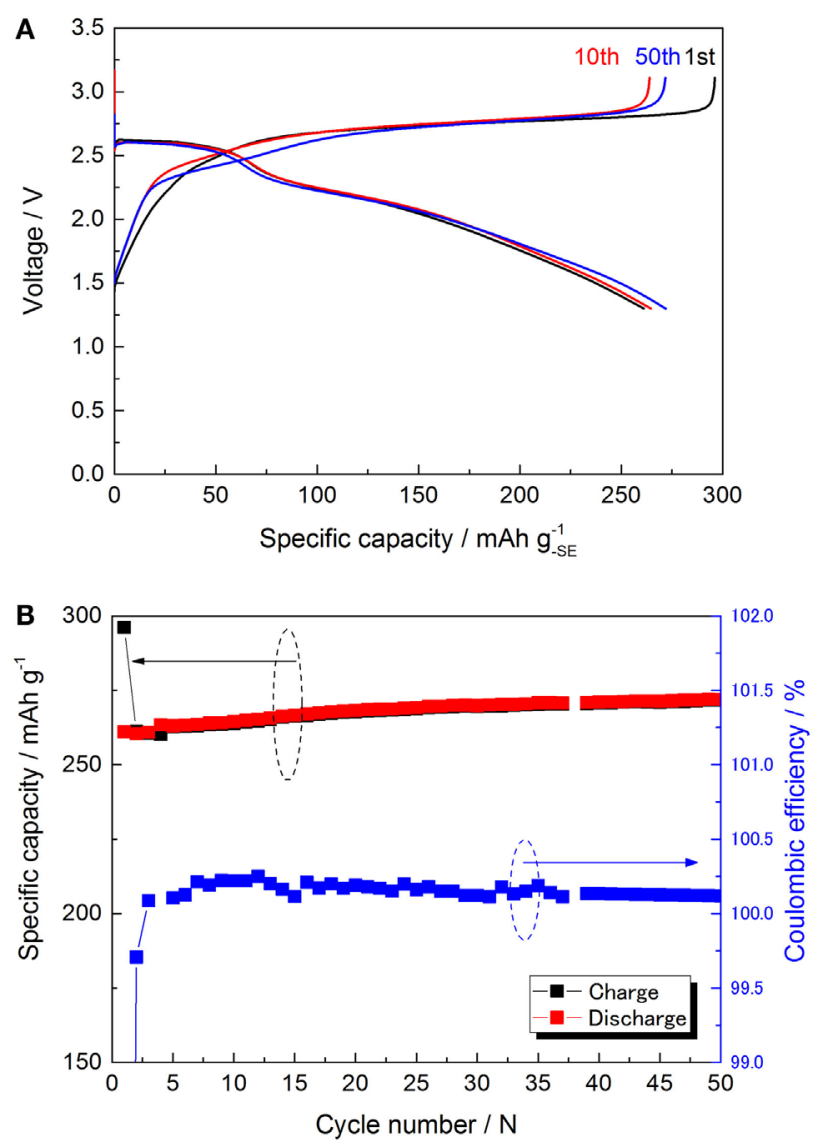

FIGURE 7 | (A) Charge/discharge curves of E-cell for 1st, 10th, and 50th cycle at $25^{\circ} \mathrm{C}$. All the charge/discharge was operated by the same condition of S-cell. (B) Charge/discharge capacities and the coulombic efficiency are plotted versus the cycle.

attenuation are plotted in Figures 7A,B. The redox capacity calculated using the weight of the electrolyte in the cathode composite was $261 \mathrm{mAh} \mathrm{g}_{-\mathrm{SE}}^{-1}$ at 10th cycle. The charge/discharge capacities were quite stable during the cycle (the coulombic efficiency was always nearly equal to $100 \%)$. Although the actual reaction scheme is unclear, two potential plateaus were clearly observed in the discharge profile.

To examine the condition of the electrolyte in the C-SE composite, we measured Raman spectroscopy of our sample. However, after the ball milling, the Raman shift related to the electrolyte $\left(420 \mathrm{~cm}^{-1}, \mathrm{PS}_{4}^{3-}\right.$ anion structure) was not observable. Other observed peaks were assigned to $\mathrm{D} / \mathrm{G}$ bands of graphite $\left(1570-1360 \mathrm{~cm}^{-1}\right)$. DSC was performed (Figure 8) and the results are summarized in Table 3. There was a significant difference between the profiles of $\mathrm{Li}_{3} \mathrm{PS}_{4}$ and $\mathrm{LiI}-\mathrm{Li}_{3} \mathrm{PS}_{4}$. $\mathrm{LiI}-\mathrm{Li}_{3} \mathrm{PS}_{4}$ exhibited a large peak at $160.9^{\circ} \mathrm{C}$. This exothermic peak might be related to the reorientation and crystallization of LiI. In the scan, the glass transition appeared just before the crystallization of LiI. The heat flow decreases slightly in the SE and C-SE samples. Furthermore, the other peaks related to $\mathrm{Li}_{3} \mathrm{PS}_{4}$ (crystallizing and transformation to the thio-LISICON phase) showed high temperature shifts. 
The peak pattern of the C-SE composite was unchanged after ball milling with activated carbon. However, the sharp peak shifted to high temperature in comparison with $\mathrm{LiI}-\mathrm{Li}_{3} \mathrm{PS}_{4}$. The reason for this high temperature shift is obscure. In the C-S-SE sample, the peak pattern was completely changed by the ball milling. The sulfur $\left(\mathrm{S}_{8}\right)$ generally does not show any exothermic peak, and only endothermic melting peaks were observed before $300^{\circ} \mathrm{C}$. However, the C-S-SE composite showed only a small endothermic peak around $107^{\circ} \mathrm{C}$ and two exothermic peaks. The presence of excess sulfur certainly changes the chemical environment and must be promoting alternate chemical reactions. Unfortunately, it was still not clear whether the materials were changed by the heating during the DSC or by the mechanical milling.

\section{DISCUSSION}

\section{Characteristic of $\mathrm{Lil}^{-\mathrm{Li}_{3} \mathrm{PS}_{4}}$}

In this paper, we have demonstrated two types of lithium metal secondary cells using a solid-state electrolyte based on an amorphous $\mathrm{LiI}-\mathrm{Li}_{3} \mathrm{PS}_{4}$. This electrolyte consists of $48 \mathrm{~mol} \%$

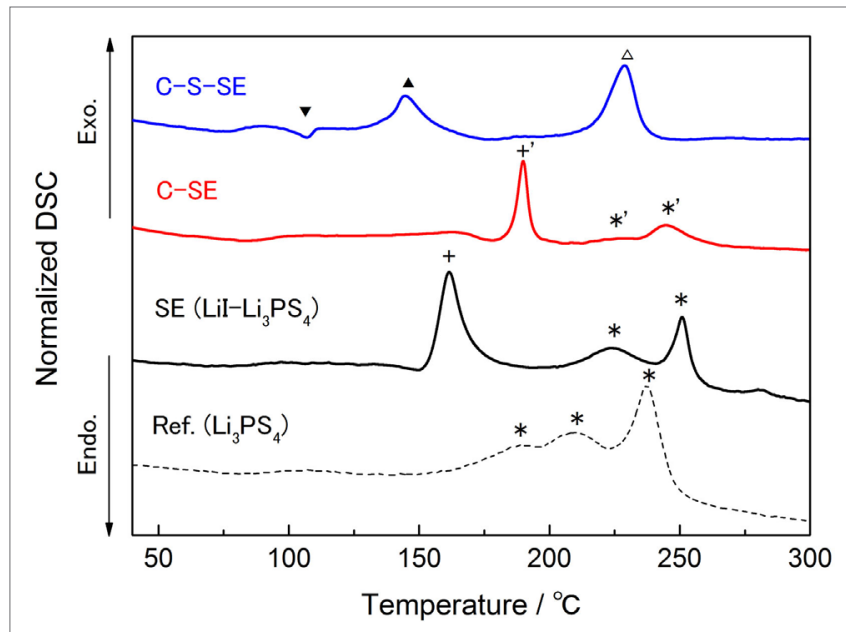

FIGURE 8 | DSC chart for the electrolytes and composites at the first heating. The heat flow was normalized by the sample weight. DSC scan rate was $2^{\circ} \mathrm{C} \mathrm{min}^{-1}$. ortho- $\mathrm{Li}_{3} \mathrm{PS}_{4}$, and the $52 \mathrm{~mol} \%$ of LiI. Although LiI is an ionic conductive material $\left(3.2 \mu \mathrm{S} \mathrm{cm} \mathrm{cm}^{-1}\right)$ (Rao et al., 1978), it is impossible to explain the improvement of ionic conductivity by the addition of $\mathrm{LiI}$ to $\mathrm{Li}_{3} \mathrm{PS}_{4}$, because of the poorer conductivity of LiI than that of $\mathrm{Li}_{3} \mathrm{PS}_{4}$. We assumed that the carrier number did not significantly change upon 52 mol\% substitution by LiI compared to amorphous $\mathrm{Li}_{3} \mathrm{PS}_{4}$. The $\mathrm{PS}_{4}$ anion actually has a symmetrical tetrahedron structure, and substitution with LiI replaces this highly symmetric spherical anion in the framework. This substitution influences the probability of the ion exchange between anions and $\mathrm{Li}^{+}$in the mixed electrolytes and increases the total ionic conductivity. However, the details of the phenomenon are still unclear, requiring further investigation. The $\mathrm{LiI}-\mathrm{Li}_{3} \mathrm{PS}_{4}$ showed a high ionic conductivity, and this improved the cell performance, especially for the S-cell in comparison with our previous study (Ito et al., 2014). Unfortunately, $\mathrm{LiI}-\mathrm{Li}_{3} \mathrm{PS}_{4}$ is unstable at high potentials $(>2.7 \mathrm{~V})$ probably due to oxidation of $\mathrm{I}^{-}$. In the NCA cell, the capacity fade in the cycle test is much larger compared to previous results although the anode is different. On the other hand, the S cell showed very stable cycles (even though the utilization of the anode is deeper in the $S$ cell); the electrolyte is at least as stable against the $\mathrm{Li} / \mathrm{Li}^{+}$redox reaction. Although $\mathrm{LiI}-\mathrm{Li}_{3} \mathrm{PS}_{4}$ may not be applicable to a $4 \mathrm{~V}$ system, it could be used for a metal lithium secondary battery with a high coulombic efficiency.

At this point, one may wonder whether the electrolyte material in the separate layer plays any role on the charge-discharge capacities. Hakari et al. (2015) have already demonstrated that the cathode composite without sufficient electronic conductivity does not allow any observable redox reactions. In our system, the electrical conductivity is given to the cathode composite by ball milling the SE with carbon to form complexes. Therefore, the SE in the separator region has no contribution in the capacity of the battery.

\section{Exact Reactions in S Cell}

The charge/discharge curves nearly emulated the theoretical redox capacity of sulfur. However, as described above, the charge/ discharge capacities must be based on the summation of redox capacities of sulfur and SE, because the electrolyte shows reversible redox capacity in the same potential range 3.1-1.3 $\mathrm{V}$ versus $\mathrm{Li} / \mathrm{Li}^{+}$. The cathode composite consists of $50 \mathrm{wt} \%$ (SE) and $37 \mathrm{wt} \%$ (sulfur). Considering the reversible capacity of the electrolyte,

TABLE 3 | Summary of the DSC analysis of the samples.

Sample

Peak top $/{ }^{\circ} \mathrm{C}$ [heat capacity $\left.(\mathrm{J} / \mathrm{g})\right]$

\begin{tabular}{|c|c|c|c|}
\hline & \\
\hline & Sulfur related & Lil related & $\mathrm{Li}_{3} \mathrm{PS}_{4}$ related \\
\hline Ref. $\left(\mathrm{Li}_{3} \mathrm{PS}_{4}\right)$ & & & $\begin{array}{l}{ }^{*} 188.8(-17.1)^{x} \\
{ }^{\star} 208.3(-17.8)^{x} \\
{ }^{\star} 237.3(-28.6)^{x}\end{array}$ \\
\hline $\mathrm{SE}\left(\mathrm{Li}_{3} \mathrm{PS}_{4}-\mathrm{Lil}\right)$ & & $+160.9(-18.5)$ & $\begin{array}{l}{ }^{*} 224.2(-9.1)^{x} \\
{ }^{*} 250.6(-9.1)^{x}\end{array}$ \\
\hline $\mathrm{C}-\mathrm{SE}(\mathrm{SE}=80 \%)$ & & +190.0 (-7.2) & $\begin{array}{l}{ }^{*} 226.8(-1.2)^{x} \\
{ }^{*} 244.5(-4.8)^{x}\end{array}$ \\
\hline
\end{tabular}

C-S-SE $(S=37 \%, S E=50 \%)$ 


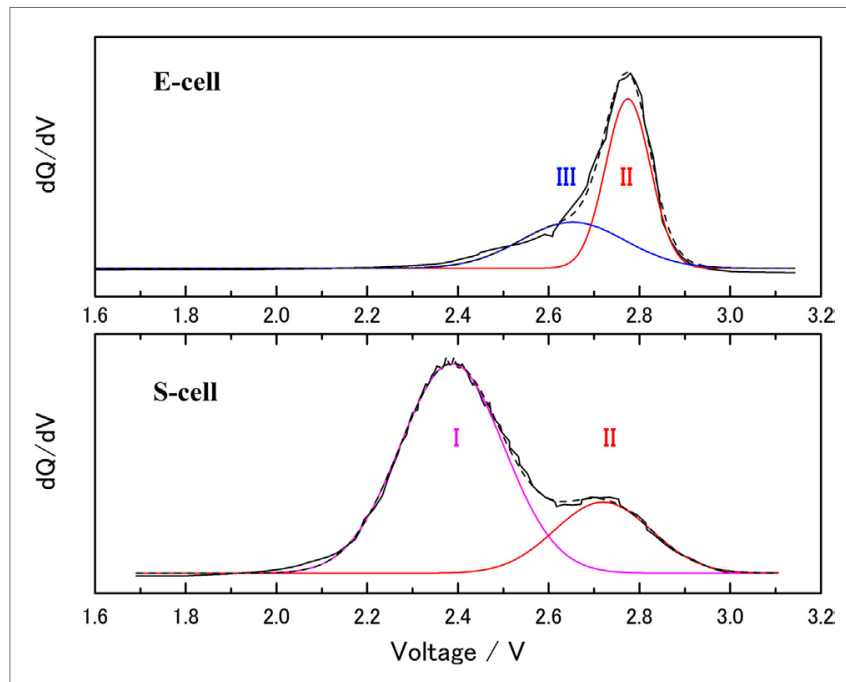

FIGURE 9 | dQ/dV plot of the charge process for S-cell (bottom) and E-cell (upper). Gaussian peak fitting was performed onto the $\mathrm{dQ} / \mathrm{dV}$ data with $R^{2}>0.998$. Each peak consists of I: main red-ox reaction of sulfur, II: red-ox capacity with poly-condensation of Li3PS4, and III: red-ox capacity of Lil.

the net capacity of sulfur was estimated. For estimating the each value, $\mathrm{dQ} / \mathrm{dV}$ profiles of S- and E-cell were examined and are presented in Figure 9. The main peak in region I (around 2.37 V) including a shoulder peak around $2.19 \mathrm{~V}$ represents the majority of the reaction in S-cell. Region II (around $2.75 \mathrm{~V}$ ) is not generally observed in a typical Li-S cell. In the dQ/dV of the S-cell, the areas assigned in regions I and II were separated by Gaussian peak fitting $\left(R^{2}>0.998\right)$. The peak area of region II in the S-cell was about $25 \%$ of the total integrated area between 1.8 and $3.0 \mathrm{~V}$. If it is assumed that the extra capacity originated from the reaction of the electrolyte at $2.75 \mathrm{~V}$, the net sulfur redox capacity was about $75 \%$ of the apparent sulfur specific capacity $\left(1600 \mathrm{mAh} \mathrm{g}_{-\mathrm{s}}^{-1}\right)$ and was equal to $1200 \mathrm{mAh} \mathrm{g}_{-s}^{-1}$. For the E-cell, the peak could be separated in two peaks. One of them gives the same potential with region II. The second peak (region III) appeared at $2.65 \mathrm{~V}$. The ratio of the peak areas for region II:III is 61:39. We have calculated and estimated the reaction based on the electrolyte composition. There was only one possibility that the summation of the redox capacity of $\mathrm{LiI}$ and $\mathrm{Li}_{3} \mathrm{PS}_{4}$ (higher than two electrons reaction) can provide the capacity of $250 \mathrm{~mA} \mathrm{~g}^{-1}$ for the SE.

$$
\begin{aligned}
& \mathrm{LiI} \rightarrow \mathrm{Li}^{+}+\mathrm{I}+\mathrm{e}^{-}\left(200 \mathrm{mAhg}^{-1}\right) \\
& \mathrm{Li}_{3} \mathrm{PS}_{4} \rightarrow \mathrm{xLi}^{+}+\mathrm{Li}_{(3-x)} \mathrm{PS}_{4} \text { (condensation) } \\
& +\mathrm{xe}^{-}\left(\mathrm{x}=1: 149,2: 298,3: 449 \mathrm{mAhg}^{-1}\right) \\
& \text { Total : } 0.52 \mathrm{LiI}-0.48 \mathrm{Li}_{3} \mathrm{PS}_{4} \rightarrow \mathrm{xLi}^{+} \\
& +\mathrm{I}+\mathrm{Li}_{(3-\mathrm{x})} \mathrm{PS}_{4} \text { (condensation) } \\
& +(\mathrm{x}+1) \mathrm{e}^{-}\left(\mathrm{x}=1: 176,2: 247,3: 319 \mathrm{mAhg}^{-1}\right)
\end{aligned}
$$

Although there are some unclear points (e.g., the exact formation of the anions in the cathode composite), LiI and two electron redox of $\mathrm{Li}_{3} \mathrm{PS}_{4}(3 \geqq x \geqq 2)$ were suitable for considering the reversible capacity of the $\mathrm{LiI}-\mathrm{Li}_{3} \mathrm{PS}_{4}$, which was used in this study. Because of the unusual DSC peaks observed in the C-S-SE composite, carbon and sulfur might also contribute to the highly complicated active material. Although further investigation is required to clarify this redox system, it is clear that the solid-state electrolyte, $\mathrm{LiI}-\mathrm{Li}_{3} \mathrm{PS}_{4}$, has scope for use in real cell reactions.

\section{CONCLUSION}

A sulfide-based $\mathrm{SE}$, amorphous $\mathrm{LiI}-\mathrm{Li}_{3} \mathrm{PS}_{4}$, was prepared by mechanical milling. The ionic conductivity was determined to be $1.2 \mathrm{mS} \mathrm{cm}^{-1}$ at $25^{\circ} \mathrm{C}$ with an activation energy of $29.1 \mathrm{~kJ} \mathrm{~mol}^{-1}$. We have demonstrated the successful fabrication of two types of lithium secondary cells using $\mathrm{LiI}-\mathrm{Li}_{3} \mathrm{PS}_{4}$. In the NCA-cell, the cell performance improved in comparison to the $\mathrm{Li}_{3} \mathrm{PS}_{4}$ adopted cell in our previous study, except for the cycle ability. Due to its poor electrochemical stability of $\mathrm{LiI}-\mathrm{Li}_{3} \mathrm{PS}_{4}$, the cycle performance was unsatisfactory in the $4-\mathrm{V}$ system. On the contrary, the cycle performance was significantly improved in the S-cell using the same electrolyte compared to our previous study. The high coulombic efficiency above $99.9 \%$ during charge-discharge cycle test was verified in the S-cell. This indicates that the cell can basically operate 1000 cycles without reserve lithium capacity in terms of the figure of merit.

Interestingly, the $\mathrm{C}-\mathrm{SE}$ composite electrochemically reacted and clearly showed a reversible capacity in the potential range of 3.1-1.3 V versus $\mathrm{Li} / \mathrm{Li}^{+}$. Although the exact reaction needs to be clarified, the stable capacity was about $260 \mathrm{mAh} \mathrm{g}^{-1}$. Also, a cooperative reaction between sulfur, $\mathrm{LiI}$, and $\mathrm{Li}_{3} \mathrm{PS}_{4}$ was observed in the C-S-SE composite. The coulombic efficiency was extremely high, even though some complex reaction was expected. Also, no evidence for a polysulfide redox shuttle was observed within 100 cycles. These facts indicate that the solid-state electrolyte and its adopted system is one of the most promising approaches for producing high-capacity lithium secondary batteries.

\section{AUTHOR CONTRIBUTIONS}

YA and SI proposed the idea and strategy for the experimental work. SI, SF, RO, and TY designed the experiments and performed the synthesis and characterization of the samples in addition to the electrochemical measurements. The experimental data were analyzed and the manuscript was written by YA and TW. The entire project was coordinated by YP and SD.

\section{ACKNOWLEDGMENTS}

This work is financially supported by Samsung Electronics. The authors acknowledge Prof. Machida (Konan University) for valuable discussion on the solid electrolyte and also express their sincere gratitude to Prof. Price (Western Sydney University) for improving the manuscript. 


\section{REFERENCES}

Bates, J. B., Dudney, N. J., Gruzalski, G. R., Zuhr, R. A., Choudhury, A., Luck, C. F., et al. (1993). This volume contains the Proceedings of the 6th International Meeting on Lithium Batteries Fabrication and characterization of amorphous lithium electrolyte thin films and rechargeable thin-film batteries. J. Power Sources 43, 103-110. doi:10.1016/0378-7753(93)80106-Y

Hakari, T., Nagao, M., Hayashi, A., and Tatsumisago, M. (2015). All-solid-state lithium batteries with $\mathrm{Li}_{3} \mathrm{PS}_{4}$ glass as active material. J. Power Sources 293, 721-725. doi:10.1016/j.jpowsour.2015.05.073

Ito, S., Fujiki, S., Yamada, T., Aihara, Y., Park, Y., Kim, T. Y., et al. (2014). A rocking chair type all-solid-state lithium ion battery adopting $\mathrm{Li}_{2} \mathrm{O}-\mathrm{ZrO}_{2}$ coated $\mathrm{LiNi}_{0.8} \mathrm{Co}_{0.15} \mathrm{Al}_{0.05} \mathrm{O}_{2}$ and a sulfide based electrolyte. J. Power Sources 248 , 943-950. doi:10.1016/j.jpowsour.2013.10.005

Kamaya, N., Homma, K., Yamakawa, Y., Hirayama, M., Kanno, R., Yonemura, M., et al. (2011). A lithium superionic conductor. Nat. Mater. 10, 682-686. doi:10.1038/nmat3066

Lin, Z., Liu, Z., Fu, W., Dudney, N. J., and Liang, C. (2013). Lithium polysulfidophosphates: a family of lithium-conducting sulfur-rich compounds for lithium-sulfur batteries. Angew. Chem. Int. Ed. 52, 7460-7463. doi:10.1002/ anie. 201300680

Mercier, R., Malugani, J.-P., Fahys, B., and Robert, G. (1981). Proceedings of the International Conference on Fast Ionic Transport in Solids Superionic conduction in $\mathrm{Li}_{2} \mathrm{~S}-\mathrm{P}_{2} \mathrm{~S}_{5}$-LiI glasses. Solid State Ionics 5, 663-666. doi:10.1016/0167-2738(81)90341-6

Nagata, H., and Chikusa, Y. (2014). A lithium sulfur battery with high power density. J. Power Sources 264, 206-210. doi:10.1016/j.jpowsour.2014.04.106

Ogawa, M., Kanda, R., Yoshida, K., Uemura, T., and Harada, K. (2012). Highcapacity thin film lithium batteries with sulfide solid electrolytes. J. Power Sources 205, 487-490. doi:10.1016/j.jpowsour.2012.01.086

Ohtomo, T., Hayashi, A., Tatsumisago, M., and Kawamoto, K. (2013). Allsolid-state batteries with $\mathrm{Li}_{2} \mathrm{O}-\mathrm{Li}_{2} \mathrm{~S}-\mathrm{P}_{2} \mathrm{~S}_{5}$ glass electrolytes synthesized by two-step mechanical milling. J. Sol. St. Electrochem. 17, 2551-2557. doi:10.1007/ s10008-013-2149-5

Rangasamy, E., Liu, Z., Gobet, M., Pilar, K., Sahu, G., Zhou, W., et al. (2015). An iodide-based $\mathrm{Li}_{7} \mathrm{P}_{2} \mathrm{~S}_{8} \mathrm{I}$ superionic conductor. J. Am. Chem. Soc. 137, 1384-1387. doi:10.1021/ja508723m

Rao, B. M. L., Silbernagel, B. G., and Jacobson, A. J. (1978). Evaluation of solid electrolytes for high temperature lithium batteries: a preliminary study. J. Power Sources 3, 59-66. doi:10.1016/0378-7753(78)80005-6

Scrosati, B., and Garche, J. (2010). Lithium batteries: status, prospects and future. J. Power Sources 195, 2419-2430. doi:10.1016/j.jpowsour.2009.11.048

Tatsumisago, M., Hama, S., Hayashi, A., Morimoto, H., and Minami, T. (2002). New lithium ion conducting glass-ceramics prepared from mechanochemical $\mathrm{Li}_{2} \mathrm{~S}-$ $\mathrm{P}_{2} \mathrm{~S}_{5}$ glasses. Solid State Ionics 15, 635-640. doi:10.1016/S0167-2738(02)00509-X

Weppner, W. (1981). Proceedings of the International Conference on Fast Ionic Transport in Solids Trends in new materials for solid electrolytes and electrodes. Solid State Ionics 5, 3-8. doi:10.1016/0167-2738(81)90186-7

Yamada, T., Ito, S., Omoda, R., Watanabe, T., Aihara, Y., Agostini, M., et al. (2015). All solid-state lithium-sulfur battery using a glass-type $\mathrm{P}_{2} \mathrm{~S}_{5}-\mathrm{Li}_{2} \mathrm{~S}$ electrolyte: benefits on anode kinetics. J. Electrochem. Soc. 162, A646-A651. doi:10.1149/2.0441504jes

Conflict of Interest Statement: The authors declare that the research was conducted in the absence of any commercial or financial relationships that could be construed as a potential conflict of interest.

Copyright $\odot 2016$ Aihara, Ito, Omoda, Yamada, Fujiki, Watanabe, Park and Doo. This is an open-access article distributed under the terms of the Creative Commons Attribution License (CC BY). The use, distribution or reproduction in other forums is permitted, provided the original author(s) or licensor are credited and that the original publication in this journal is cited, in accordance with accepted academic practice. No use, distribution or reproduction is permitted which does not comply with these terms. 